\title{
Preparation and characterization of $\mathrm{CoAl}_{2} \mathrm{O}_{4}$ blue ceramic nano pigments by attrition milling
}

\author{
Ki-Chan Lee,**, Jong-Won Yoon**, Jin-Ho Kim*, Kwang-Taek Hwang* and Kyu-Sung Han*,† \\ *Icheon Branch, Korea Institute of Ceramic Engineering and Technology, Icheon 467-843, Korea \\ **Department of Advanced Materials Science and Engineering, Dankook University, Cheonan 330-714, Korea \\ (Received August 26, 2013) \\ (Revised September 13, 2013) \\ (Accepted September 23, 2013)
}

\begin{abstract}
Cobalt aluminate $\left(\mathrm{CoAl}_{2} \mathrm{O}_{4}\right)$ is a highly stable pigment with excellent resistance to light, weather, etc., which has resulted in widespread use as a ceramic pigment. Due to the unique optical characteristics, $\mathrm{CoAl}_{2} \mathrm{O}_{4}$ is generally used as a coloring agent to decorate porcelain products, glass, paints and plastics. Here, $\mathrm{CoAl}_{2} \mathrm{O}_{4}$ pigments were synthesized by polymerized complex method and solid state reaction. Then $\mathrm{CoAl}_{2} \mathrm{O}_{4}$ pigment were grinded using the attrition milling with $1 \mathrm{~mm}$ size zirconia ball for 3 hours. The attrition milling process was performed at the constant speed of $800 \mathrm{rpm}$ and ball to powder weight ratio (BPR) was $100: 1$. The characteristics of synthesized pigment were analyzed by X-ray diffraction (XRD), field emission scanning electron microscopy (FE-SEM), transmission electron microscopy (TEM), particle size analyser (PSA) and CIE L*a*b* The XRD patterns of $\mathrm{CoAl}_{2} \mathrm{O}_{4}$ show single phase spinel structure. The particle size of $\mathrm{CoAl}_{2} \mathrm{O}_{4}$ measured by FE-SEM, TEM and PSA analysis was in the range of 100 200 nm. The blue color of obtained $\mathrm{CoAl}_{2} \mathrm{O}_{4}$ pigments could be confirmed through CIE L*a*b* measurement.
\end{abstract}

Key words $\mathrm{CoAl}_{2} \mathrm{O}_{4}$, Polymerized complex method, Solid state reaction, Ceramic pigment, attrition milling

\section{어트리션밀을 이용한 $\mathrm{CoAl}_{2} \mathrm{O}_{4}$ 나노 무기 안료의 제조 및 특성 평가}

\section{이기찬***, 윤종원**, 김진호*, 황광택*, 한규성*,}

*한국세라믹기술원 이천분원, 이천, 467-843

**단국대학교 신소재공학과, 천안, 330-714

(2013년 8월 26일 접수)

(2013년 9월 13일 심사완료)

(2013년 9월 23일 게재확정)

요 약 $\mathrm{CoAl}_{2} \mathrm{O}_{4}$ 는 열적 및 화학적으로 매우 안정한 물질이며 독특한 광학적 특성으로 인해 도자기 제품, 유리, 페인트, 플라스틱을 장식하는 세라믹 착색제로 사용되어져 왔다. 본 연구에서는 착체중합법(Polymerized complex method)과 고상합 성법(Solid state reaction)을 이용하여 단상의 $\mathrm{CoAl}_{2} \mathrm{O}_{4}$ 청색 무기 안료를 합성하였고, 잉크젯 프린팅용 잉크로의 응용 시 노 즐 막힘 및 분산안정성과 같은 문제점을 방지하기 위해 고에너지 밀링 공정 중 하나인 어트리션밀을 이용하여 입자를 미 세화하였다. 밀링 공정은 직경 $1 \mathrm{~mm}$ 의 지르코니아 볼을 이용하여 BPR(Ball to powder weight ratio) $100: 1,800 \mathrm{rpm}$ 의 조건 에서 3시간 동안 진행되었다. 합성된 안료는 XRD, FE-SEM, TEM, PSA, 그리고 CIE L*a*b* 측정을 통하여 어트리션밀링 전후의 특성을 분석하였다. XRD 측정 결과 단상의 $\mathrm{CoAl}_{2} \mathrm{O}_{4}$ 청색 무기 안료가 합성되었고, 고에너지 밀링 공정을 통하여 100 200 nm의 입자 크기를 가지는 청색 나노 무기 안료를 얻었다.

\section{1. 서 론}

일반적으로 두 산화물 사이의 고체반응에 의해 높은

Corresponding author

Tel: +82-31-645-1404

Fax: +82-31-645-1488

E-mail:kh389@kicet.re.kr
온도에서 합성되는 $\mathrm{CoAl}_{2} \mathrm{O}_{4}$ 는 강렬한 청색을 나타내며, 열적, 화학적으로 매우 안정하다 $[1,2]$. 특유한 청색을 발색하는 특성으로 인해 $\mathrm{CoAl}_{2} \mathrm{O}_{4}$ 는 페인트, 유리, 유약, 세라믹 소지 및 법랑 등의 착색에 사용되는 청색 무기 안료로써 널리 사용되어져 왔다[3-6]. 특히 현대 주거공 간의 변화에 따라 보다 나은 제품을 위해서 형태, 문양, 색상 등의 디자인이 변화된 도자기, 타일, 위생도기 등의 
세라믹 제품이 요구되고 있는데 높은 선명도의 여러 가 지 문양으로 디자인된 타일 제품에 대한 수요 증가와 더 불어 이에 사용되는 무기 안료 개발의 중요성도 점차 커 지는 추세이다. 기존의 세라믹 제품 표면에 문양을 입히 거나 디자인을 위해 기존에 사용해 온 실크프린팅법과 전사 공정은 대량생산에는 용이하나, 세밀한 표현 및 다 양한 문양을 위해서는 새로운 판의 제작이 필요하여 제 작비가 비싸고 원료의 낭비가 심한 단점을 가지고 있다. 이러한 단점을 보완하기 위해 잉크젯 프린팅(Ink-jet printing)을 이용한 세라믹 제품 개발에 관한 연구가 진 행되고 있는데 잉크젯 프린팅 공정은 디지털 신호에 의 해 잉크를 토출시켜 원하는 시점과 공간위에 분사하여 이미지의 품질 제어가 가능하고, 잉크의 낭비가 없어 효 율성이 높고 환경적인 부하가 적은 공정이다 $[7,8]$. 하지 만 현재 사용되는 마이크로 크기의 안료 입자를 잉크젯 프린팅 시스템에 응용할 때에는 노즐 막힘, 분산안정성 과 같은 문제점이 발생하고, 이와 같은 문제점을 해결하 기 위해서는 100 $200 \mathrm{~nm}$ 의 크기를 가지는 나노 크기의 무기 안료가 필요하다 $[7,9,10]$. 잉크젯 프린팅에 사용되 는 기본 디지털 컬러는 CMYK(Cyan, Magenta, Yellow, Black)의 4색이며, 본 연구에서는 세라믹 제품에 적용되 기 위해 우수한 열적안정성 및 색채성을 가지는 청색 계 열의 세라믹 나노 안료의 합성 및 특성평가를 수행하였 다[10].

청색을 발색하는 $\mathrm{CoAl}_{2} \mathrm{O}_{4}$ 세라믹 안료를 각각 착체중 합법과 고상합성법을 이용하여 합성하였고, $\mathrm{CoAl}_{2} \mathrm{O}_{4}$ 무 기 안료의 색상 및 특성을 분석하였다. 착체중합법은 액 상합성법을 기반으로 고순도의 복합 산화물 분말을 제조 하는 화학 합성법 중 하나로 양이온들의 화학 양론적 조 성이 잘 유지되며, 균질하고 미세한 입자들로 구성된 다 성분계 복합 산화물 분말을 얻을 수 있기 때문에 분체 합성, 유리 제조, 박막 제조 등에 널리 사용되고 있다 $[11,12]$. 고상합성법의 경우 일반적으로 합성온도가 높 고 기계적 분쇄와 혼합에 의존하므로 결과물의 균일, 균 질성이 다소 떨어지나 가장 경제적이며 대량 생산공정으 로의 적용이 원활한 장점을 가지고 있다. 합성된 안료는 고에너지 밀링 공정 중 하나인 어트리션밀(Attrition mill) 을 이용하여 잉크젯 프린팅용 세라믹 잉크로의 응용이 가능한 $200 \mathrm{~nm}$ 이하의 입자크기를 가지는 나노 안료로 사용하기 위해 입자 미세화 공정을 거쳤으며 이에 따른 $\mathrm{CoAl}_{2} \mathrm{O}_{4}$ 무기 안료 입자의 결정구조 및 색상 변화를 자 세하게 분석하여 비교하였다.

\section{2. 실험방법}

$\mathrm{CoAl}_{2} \mathrm{O}_{4}$ 청색 무기 안료는 착체중합법과 고상합성법

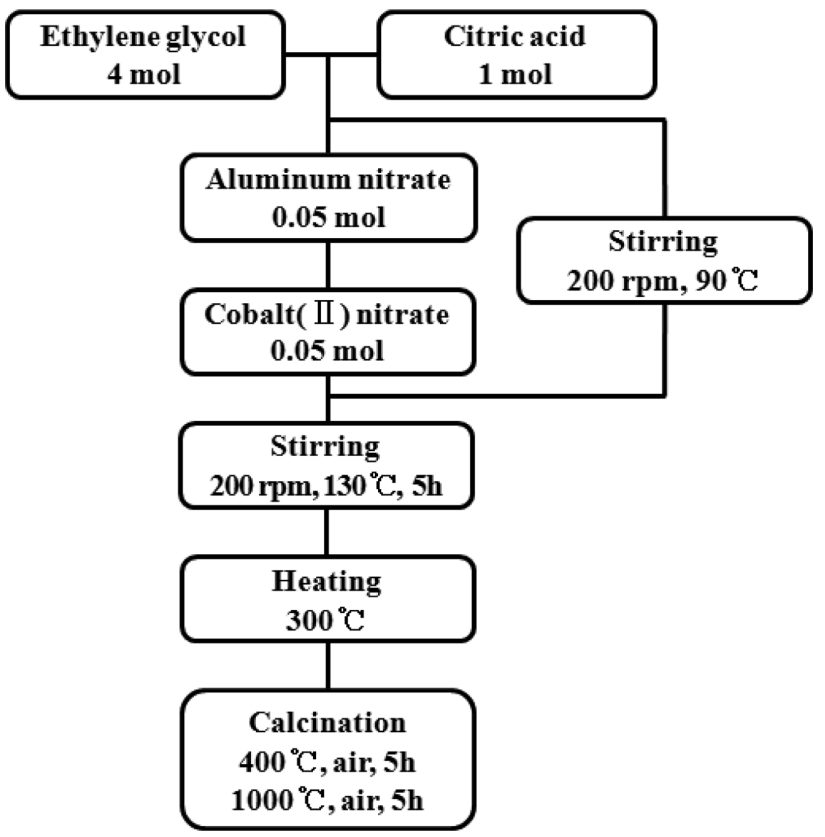

Fig. 1. The experimental procedure of $\mathrm{CoAl}_{2} \mathrm{O}_{4}$ synthesis using the polymerized complex method.

의 두 가지 공정을 이용하여 합성되었다. 먼저 착체중합법 을 이용하여 $\mathrm{CoAl}_{2} \mathrm{O}_{4}$ 청색 안료를 합성하기 위해서 출발 원료로 $\mathrm{Al}\left(\mathrm{OH}_{3}\right)_{3}\left(\mathrm{H}_{2} \mathrm{O}\right)_{9}$ (Aluminum nitrate nonahydrate, ALDRICH), $\mathrm{Co}\left(\mathrm{NO}_{3}\right)_{3}\left(\mathrm{H}_{2} \mathrm{O}\right)_{6}(\mathrm{Cobalt}(\mathrm{II})$ nitrate hexahydrate, ALDRICH)를 사용하였다. Fig. 1에 착체중합법 공정에 의한 $\mathrm{CoAl}_{2} \mathrm{O}_{4}$ 청색 안료의 합성 과정의 모식도를 나타 내었다. 안정제로 사용되는 구연산(Citric acid, DAEJUNG) $1 \mathrm{~mol}$ 과 용매로 사용되는 에틸렌글리콜(Ethylene glycol, SAMCHUN) $4 \mathrm{~mol}$ 을 hotplate stirrer를 이용하여 $90^{\circ} \mathrm{C}$ 에서 $200 \mathrm{rpm}$ 의 속도로 교반하여 용해시킨 후, 용해 된 물질에 원료 물질을 각각 $0.05 \mathrm{~mol}$ 씩 첨가하여 완전히 용해시켜 준다. 완전히 용해된 후 hotplate stirrer의 온도 를 $130^{\circ} \mathrm{C}$ 로 올려 5 시간 동안 교반하여 에스터화 반응 (esterification)을 유도한다. 에스터화 반응이 끝난 혼합 용액은 heating mantle로 옮겨 $300^{\circ} \mathrm{C}$ 로 가열하여 혼합 액속의 유기물을 증발시켜 갈색빛의 파우더로 만든다. 여기서 얻은 갈색 파우더는 전기로를 이용하여 $400^{\circ} \mathrm{C}$ 에 서 5 시간 동안 열처리하여 유기물을 제거하고 마지막으 로 $1000^{\circ} \mathrm{C}$ 에서 5 시간 동안 하소하여 $\mathrm{CoAl}_{2} \mathrm{O}_{4}$ 무기 안 료를 합성하였다[12, 13].

고상합성법의 경우에는 $\mathrm{CoAl}_{2} \mathrm{O}_{4}$ 청색 안료를 합성하기 위한 출발 원료인 $\mathrm{CoO}(325$ mesh, ALDRICH) $1 \mathrm{~mol}$ 과 $\mathrm{Al}_{2} \mathrm{O}_{3}(0.3 \mu \mathrm{m}, \mathrm{SUMITOMO}) 1 \mathrm{~mol}$ 을 직경 $10 \mathrm{~mm}$ 알루 미나 볼과 함께 플라스틱 통에 넣은 후 에탄올을 첨가하 여 3시간 동안 습식 밀링하고 혼합한 후 에탄올을 제거하 여 회색빛의 분말을 얻는다. 그 후 얻은 분말을 $1200^{\circ} \mathrm{C}$ 에 서 1시간 동안 열처리하여 $\mathrm{CoAl}_{2} \mathrm{O}_{4}$ 무기 안료를 합성하 


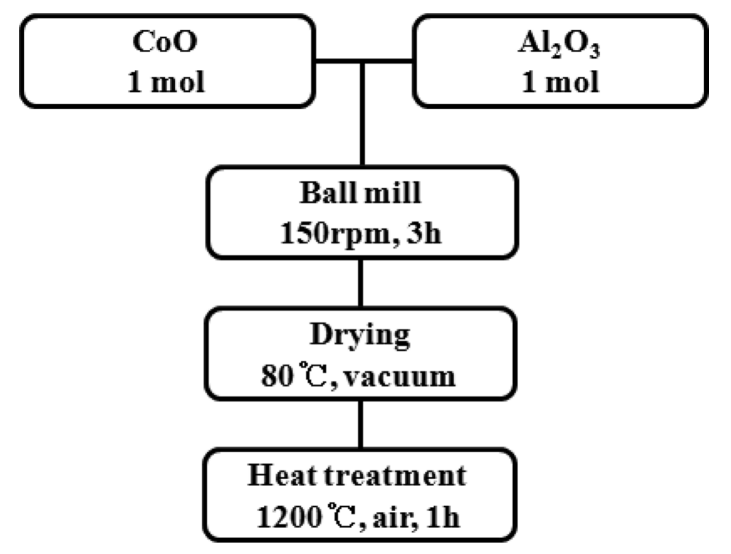

Fig. 2. The experimental procedure of $\mathrm{CoAl}_{2} \mathrm{O}_{4}$ synthesis using the solid state reaction.

였다[14, 15]. Fig. 2는 고상합성법에 의한 $\mathrm{CoAl}_{2} \mathrm{O}_{4}$ 청 색 안료의 합성 과정을 모식도로 보여주고 있다.

이와 같이 착체중합법과 고상합성법으로 제조된 $\mathrm{CoAl}_{2} \mathrm{O}_{4}$ 무기 안료를 잉크젯 프린팅용 200 대의 입자 크기를 가지는 나노 무기 안료로 만들기 위해 어트리션 밀(KMD-1S, 고려소재개발)을 이용하여 입자 미세화 공 정을 진행하였다. 어트리션밀은 용기내의 회전팔(impeller) 이 볼과 분말을 교반 시키도록 하여 볼과 볼 사이, 볼과 회전팔간의 충격력, 그리고 볼과 자 내벽 간 마찰에 의 한 전단력에 의해 밀링이 이루어진다. Fig. 3은 어트리 션밀링(attrition milling)의 개략도를 나타낸 것이다. 밀 링 공정에는 직경 $1 \mathrm{~mm}$ 의 지르코니아 볼을 이용하였고, BPR(Ball to Powder Ratio)는 100:1의 조건으로 에탄 올과 함께 3시간 동안 습식 밀링을 진행하였다. 밀링 후 $50 \mathrm{mesh}$ 의 체로 볼을 1 차 분류하고, $325 \mathrm{mesh}$ 체를 이 용하여 2차로 안료를 분리한 후 건조하여 최종적으로 청색 나노 무기 안료를 얻었다.

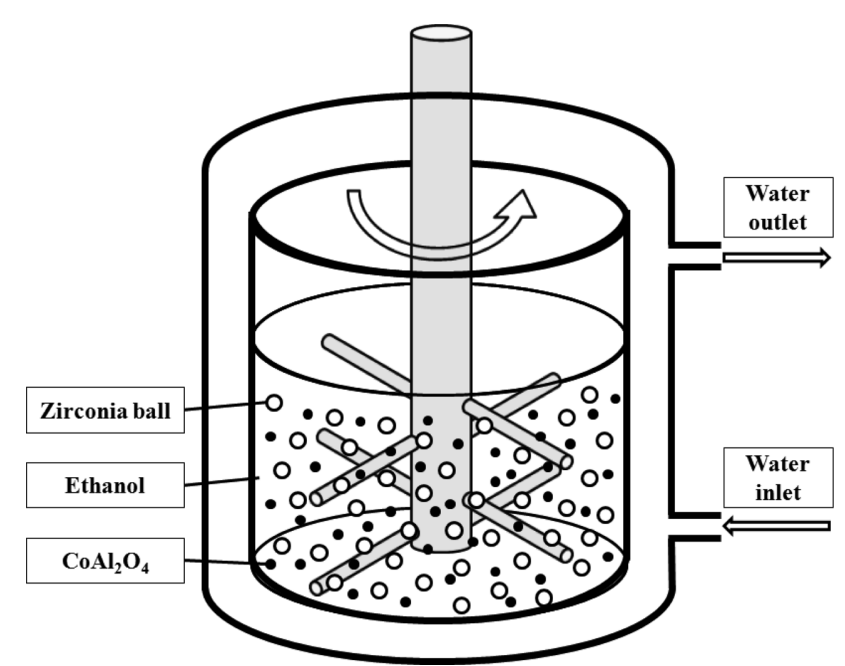

Fig. 3. Schematic drawing of the attrition milling process.
어트리션밀을 통해 분쇄된 $\mathrm{CoAl}_{2} \mathrm{O}_{4}$ 청색 나노 무기 안료의 결정상을 분석하기 위해 X-ray diffraction(XRD, D/MAX2500VL/PC, Rigaku, Japan) 측정을 수행하였고, 안료의 색상은 국제조명위원회(CIE: Commissiom Internationale de I'Eclairage) 표색계의 값( $\left.\mathrm{L}^{*}, \mathrm{a}^{*}, \mathrm{~b}^{*}\right)$ 를 기 준으로 Spectrophotometer(CM-700D, Konica)를 사용하 여 측정하였다. 어트리션밀링 시간에 따른 무기 안료의 입도는 Field emission scanning electron microscope (FE-SEM, JSM-6701F, JEOL, Japan)과 Particle size analyzer(PSA, LA-950V2, HORIBA, Japan)를 통하여 분석하였고, High resolution transmission electron microscopy(HR-TEM, Tecnai G2 F30 S-Twin)을 이용 하여 나노 안료의 형상과 크기를 관찰하였다.

\section{3. 결과 및 고찰}

\section{1. $\mathrm{CoAl}_{2} \mathrm{O}_{4}$ 청색 무기 안료합성}

착체중합법과 고상합성법을 이용하여 합성된 $\mathrm{CoAl}_{2} \mathrm{O}_{4}$ 청색 무기 안료의 전반적인 특성을 비교 분석한 결과를 각각 Fig. 4와 Fig. 5에 나타내었다. Fig. 4는 착체중합 법으로 합성 후 $1000^{\circ} \mathrm{C}$ 에서 5 시간 동안 하소하여 얻은 $\mathrm{CoAl}_{2} \mathrm{O}_{4}$ 청색 무기 안료의 분석 결과를 보여주고 있다. Fig. 4(a)는 착체중합법으로 합성된 안료의 FE-SEM 이 미지로, 1 차 입자의 크기는 $50 \mathrm{~nm}$ 정도로 보여지고 있 다. 하지만 1 차 입자들이 응집되어 수 $\mu \mathrm{m}$ 크기의 2차 입자로 존재하고 있어, 잉크젯 프린팅 공정용 잉크로의 응용을 위해서는 입자의 미세화 필요성이 있음을 알 수 있다. Fig. 4(b)는 착체중합법으로 합성한 안료의 XRD 분석 결과로, 하소 전에는 $\mathrm{CoAl}_{2} \mathrm{O}_{4}$ 의 결정화가 이루어 지지 않아 비정질의 spectrum이 관찰되지만, $1000^{\circ} \mathrm{C}$ 에 서 5 시간 하소 후에는 $\mathrm{CoAl}_{2} \mathrm{O}_{4}$ 의 단일 상을 나타내는 피크가 측정되었다. Fig. 4(c)의 이미지와 같이 착체중합 법으로 합성된 $\mathrm{CoAl}_{2} \mathrm{O}_{4}$ 무기안료는 육안으로 관찰시 청 색을 발색하고 있으며, Fig. 4(d)의 CIE L*a*b* 측정결 과 $\mathrm{L}$ 값이 30.53 , $\mathrm{a}$ 값이 $-6.41, \mathrm{~b}$ 값이 -27.27 을 나타내는 것을 확인할 수 있었다.

Fig. 5는 고상합성법으로 합성한 후 $1200^{\circ} \mathrm{C}$ 에서 1 시간 동안 열처리하여 얻은 $\mathrm{CoAl}_{2} \mathrm{O}_{4}$ 청색 무기 안료의 분석 결과를 보여주고 있다. Fig. 5(a)는 고상합성법으로 합성 한 안료의 FE-SEM 이미지로, 1 차 입자의 크기는 $1 \mu \mathrm{m}$ 이하로 보여지고 있으나, Fig. 4(a)의 착체중합법으로 합 성된 시편과 같이 1 차 입자들이 응집되어 수 $\mu \mathrm{m}$ 크기 의 2차 입자로 존재하기 때문에 고상합성법으로 제조된 무기 안료 역시 미세화 공정의 필요성이 나타나게 되었 다. Fig. 5(b)는 고상합성법으로 합성한 안료의 XRD 분 

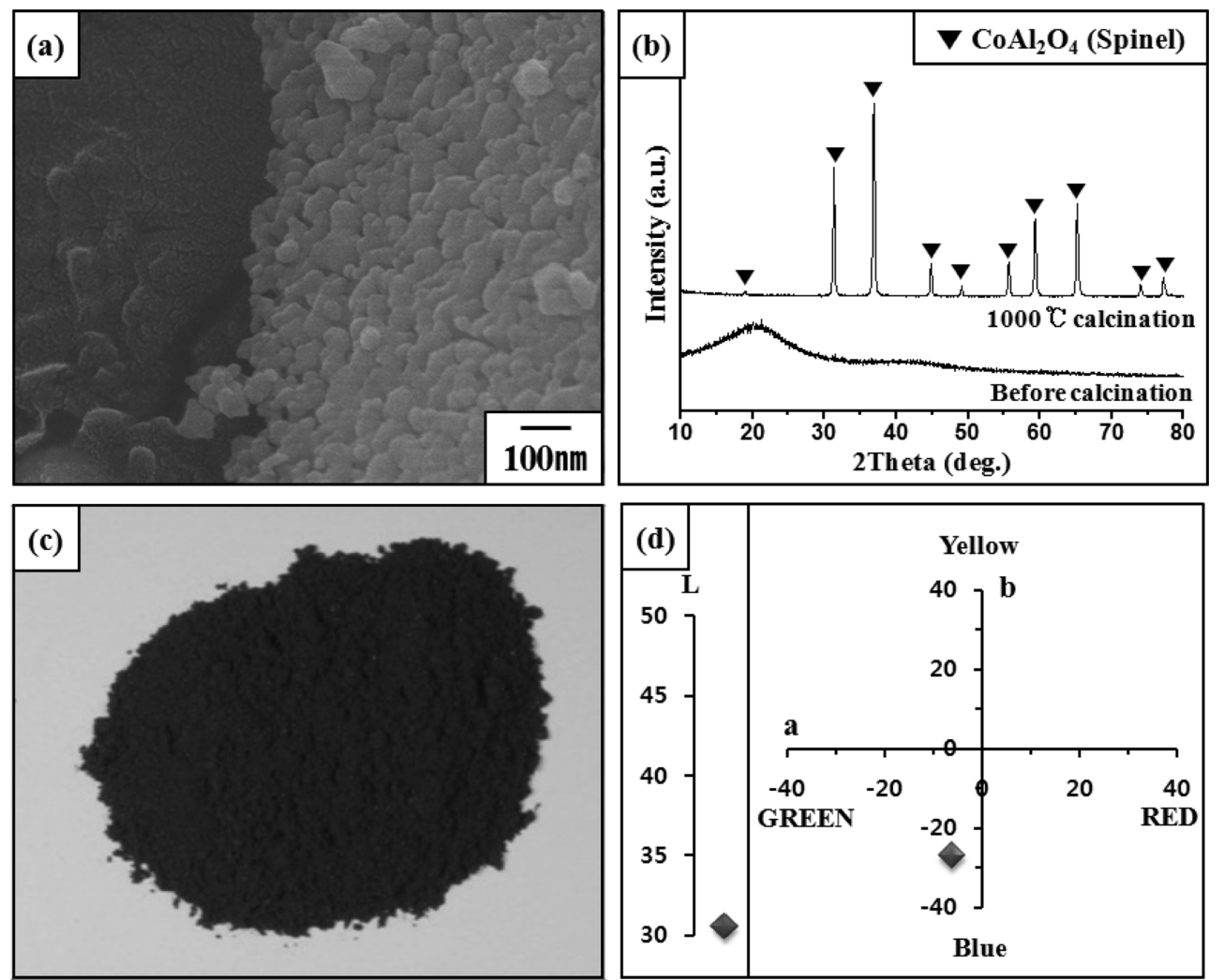

Fig. 4. (a) SEM image, (b) XRD spectra, (c) optical image and (d) CIE L*a*b* result of $\mathrm{CoAl}_{2} \mathrm{O}_{4}$ blue pigment synthesized by the polymerized complex method.
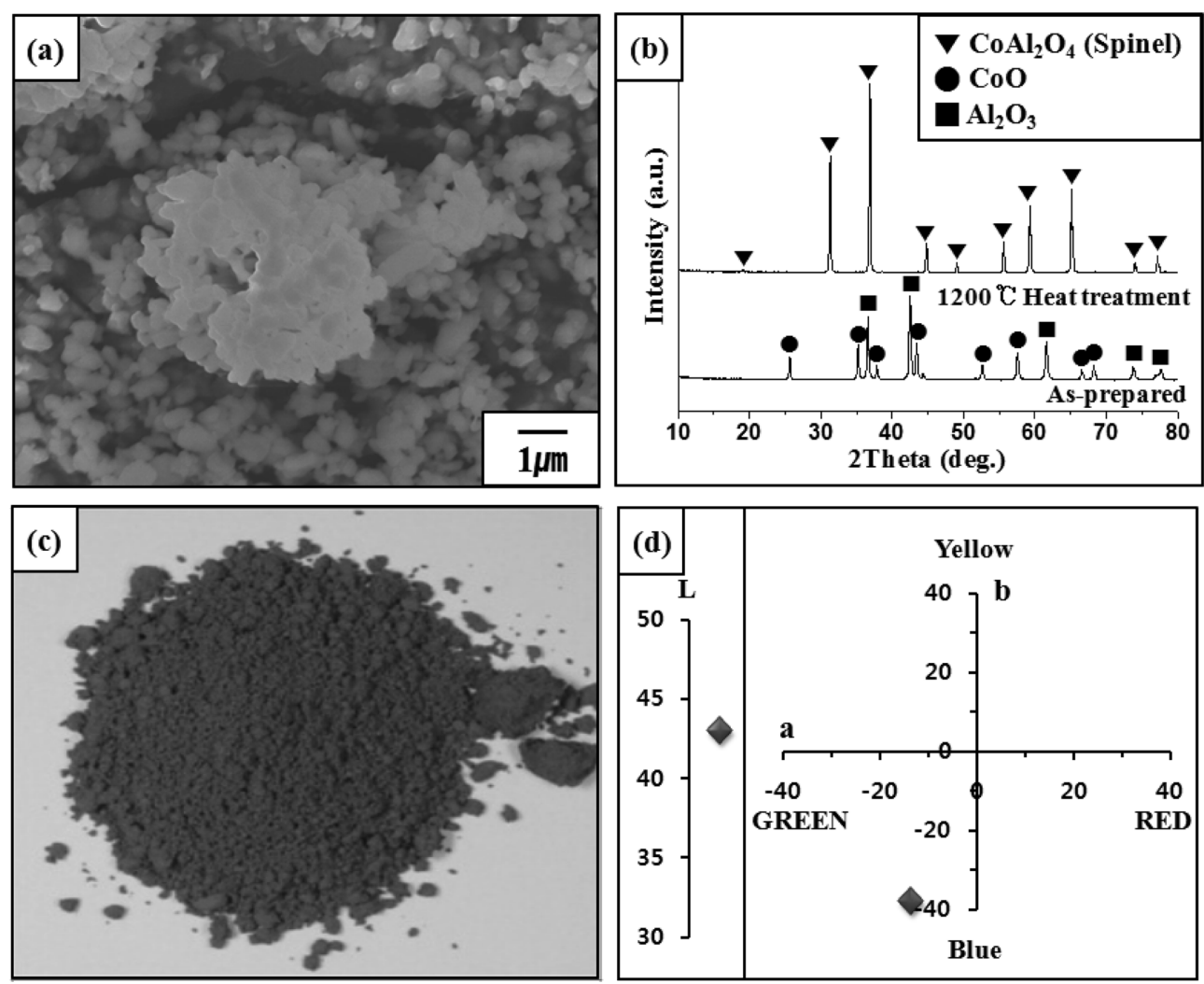

Fig. 5. (a) SEM image, (b) XRD spectra, (c) optical image and (d) CIE L*a*b* result of $\mathrm{CoAl}_{2} \mathrm{O}_{4}$ blue pigment synthesized by the solid state reaction. 
석 결과로, 열처리 전에는 출발 물질인 $\mathrm{CoO}$ 와 $\mathrm{Al}_{2} \mathrm{O}_{3}$ 의 피크가 나타나지만, $1200^{\circ} \mathrm{C}$ 에서 1 시간 동안 열처리한 결과 $\mathrm{CoAl}_{2} \mathrm{O}_{4}$ 의 단일 상을 나타내는 피크가 측정되었다. Fig. 5(d)의 CIE L*a*b* 측정결과를 통하여 고상합성법 으로 합성한 $\mathrm{CoAl}_{2} \mathrm{O}_{4}$ 무기 안료는 $\mathrm{L}$ 값이 42.98 , $\mathrm{a}$ 값이 $-13.45, \mathrm{~b}$ 값이 -37.82 를 가지며, Fig. 5(c)와 같이 청색 을 발색하는 것을 확인하였다.

이와 같이 착체중합법과 고상합성법을 이용하여 합성 한 $\mathrm{CoAl}_{2} \mathrm{O}_{4}$ 무기 안료는 모두 $\mathrm{CoAl}_{2} \mathrm{O}_{4}$ 의 단일 상을 가 지며 $\mathrm{CIE} \mathrm{L}^{*} \mathrm{a} \mathrm{b}^{*}$ 측정결과 고온에서의 열처리 후에도 안정적으로 청색을 발색하는 무기 안료임을 확인하였다.

\section{2. $\mathrm{CoAl}_{2} \mathrm{O}_{4}$ 청색 나노 무기 안료의 미세구조분석}

앞에서 착체중합법과 고상합성법을 이용하여 합성한 $\mathrm{CoAl}_{2} \mathrm{O}_{4}$ 청색 무기 안료의 경우 입자의 응집으로 인해 수 $\mu \mathrm{m}$ 의 크기를 가지는 2 차 입자로 존재하는 것을 Fig. 4(a)와 Fig. 5(a)의 FE-SEM 사진을 통하여 확인하였다. 안료 입자 크기가 수 $\mu \mathrm{m}$ 일 경우 이를 이용하여 잉크젯 프린팅용 잉크로의 응용 시 분산안정성과 함께 노즐 막 힘과 같은 문제점이 발생하므로 이를 방지하기 위해 $200 \mathrm{~nm}$ 이하의 입자크기를 가지는 나노 무기 안료가 필 요하다. 따라서 착체중합법과 고상합성법으로 합성한 두
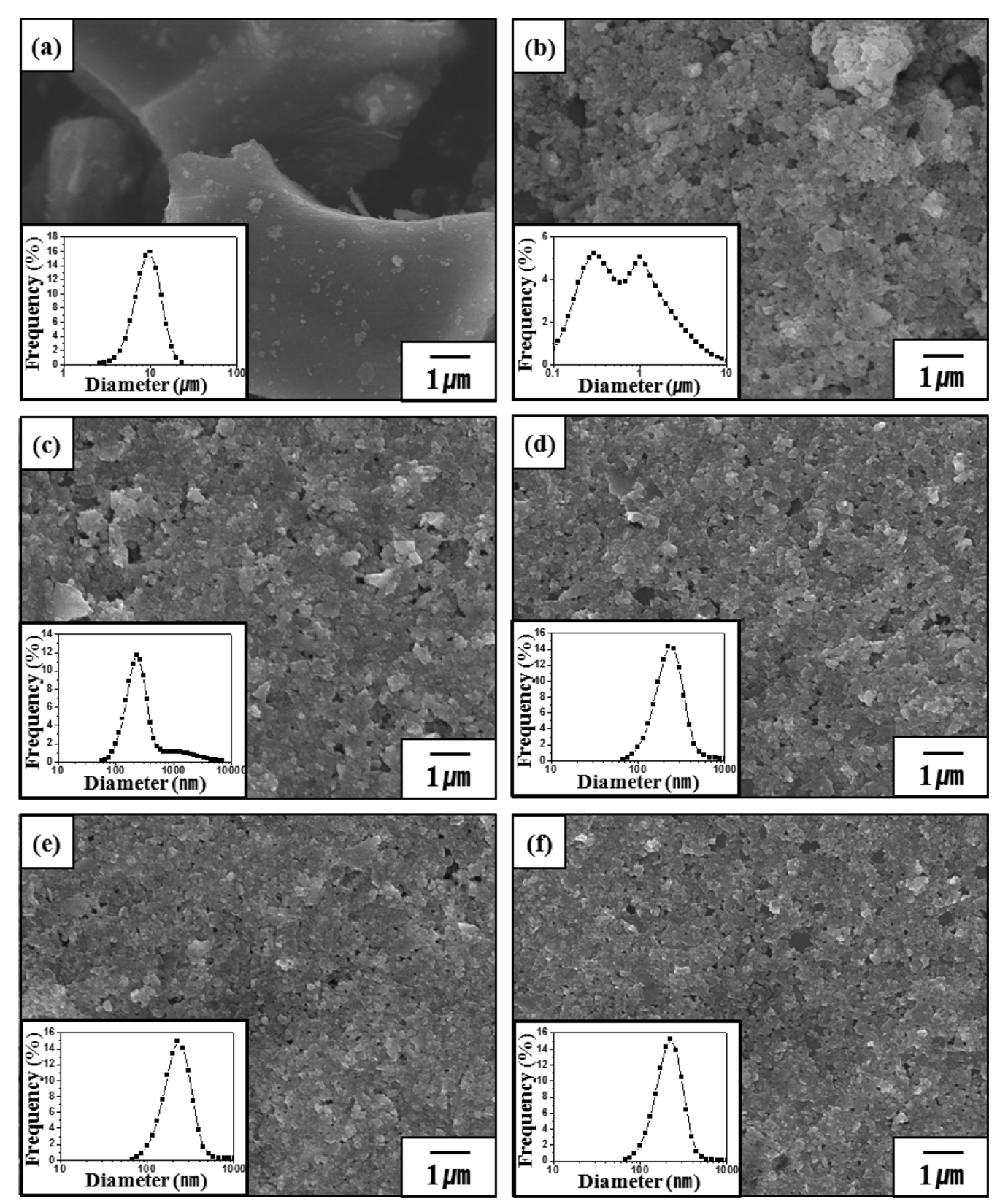

Fig. 6. SEM images of $\mathrm{CoAl}_{2} \mathrm{O}_{4}$ blue pigments prepared by the polymerized complex method after the attrition milling for (a) $0 \mathrm{~h}$, (b) $1 \mathrm{~h}$, (c) $2 \mathrm{~h}$, (d) $3 \mathrm{~h}$, (e) $4 \mathrm{~h}$, (f) $5 \mathrm{~h}$. Inset shows the particle size distribution. 
가지의 $\mathrm{CoAl}_{2} \mathrm{O}_{4}$ 무기 안료를 고에너지 밀링법 중 하나 인 어트리션밀을 이용하여 분쇄 공정을 진행하였다.

어트리션밀링에 의해 안료 입자가 균질하게 분쇄가 이 루어졌는지 보기위해 저배율 FE-SEM 이미지를 통하여 확인해 보았다. Fig. 6와 Fig. 7는 각각 착체중합법과 고 상합성법으로 제조한 안료의 어트리션밀링 시간에 따른 입도 변화를 보여주는 FE-SEM 이미지이며 PSA 측정 을 통해 얻은 입도 분포를 삽입하여 나타내었다. 합성된 $\mathrm{CoAl}_{2} \mathrm{O}_{4}$ 청색 무기 안료는 초기 수 $\mu \mathrm{m}$ 의 크기를 가지 고 있지만, 밀링 1 시간 후 급격하게 입자크기가 감소하 였고, 점차 밀링 시간이 지남에 따라 균일한 크기를 가
지는 나노 안료가 얻어진 것을 확인할 수 있었다.

어트리션밀링 시간에 따른 안료 입자의 크기 변화를 좀 더 자세하게 비교하기 위해 Fig. 8에 PSA측정을 통 한 입도 분석 결과를 나타내었다. Fig. 8(a)의 착체중합 법으로 합성된 안료의 경우 초기 $9 \mu \mathrm{m}$ 대의 입자 크기를 가지고 있지만, 1 시간 밀링 후 입자 크기가 약 $1 \mu \mathrm{m}$ 로 급격히 감소하다가, 3 시간 이후 $200 \mathrm{~nm}$ 대의 크기를 가 지는 것을 보여주고 있다. 고상합성법으로 합성된 안료 입자도 초기 $3 \mu \mathrm{m}$ 대의 입자 크기를 가지고 있지만, 1 시 간 밀링 후 입자 크기가 약 $300 \mathrm{~nm}$ 로 급격히 감소하였 고, 3시간 이후에는 입도가 $200 \mathrm{~nm}$ 이하로 감소하였다.
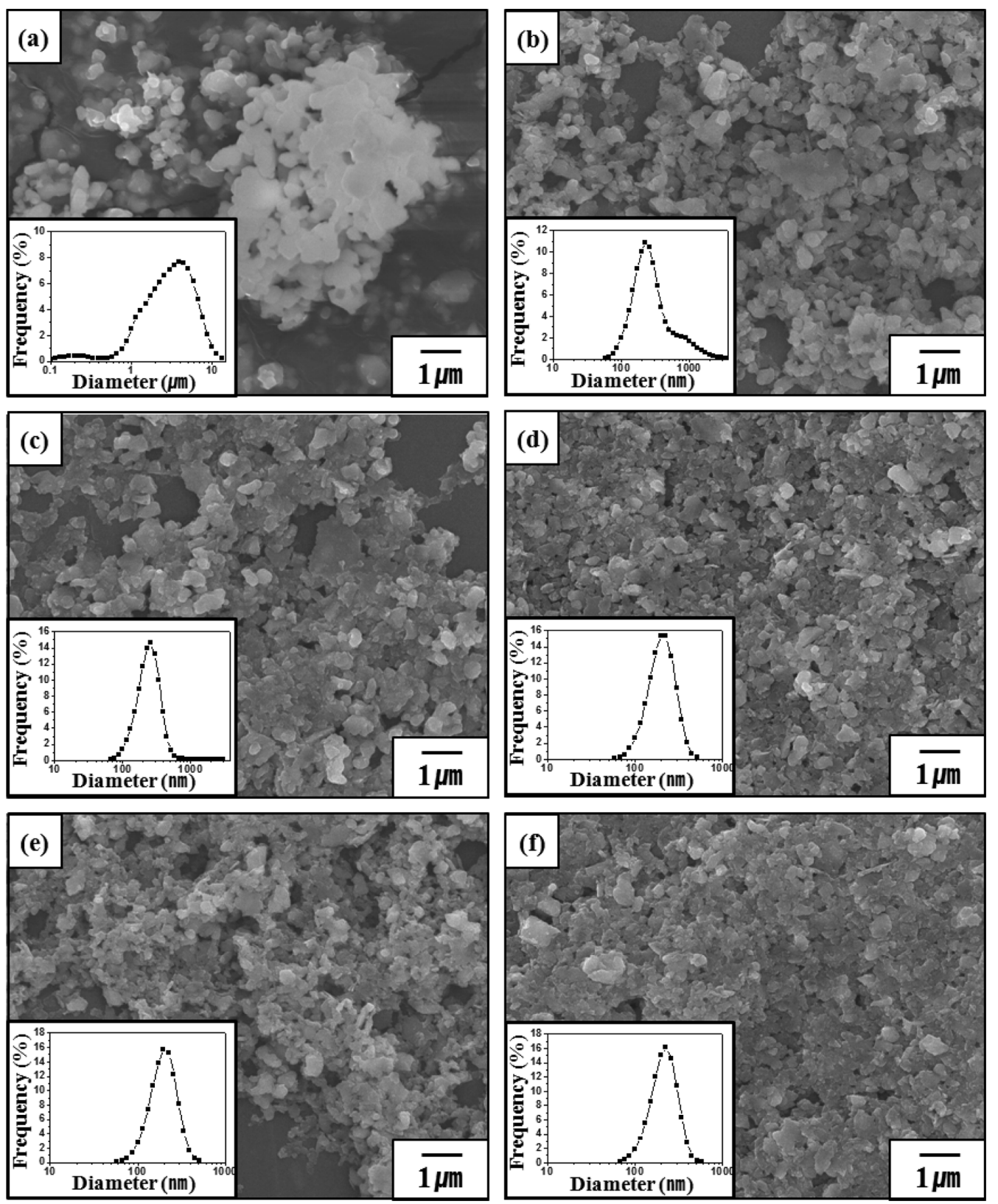

Fig. 7. SEM images of $\mathrm{CoAl}_{2} \mathrm{O}_{4}$ blue pigments prepared by the solid state reaction after the attrition milling for (a) $0 \mathrm{~h}$, (b) $1 \mathrm{~h}$, (c) $2 \mathrm{~h}$, (d) $3 \mathrm{~h}$, (e) $4 \mathrm{~h}$, (f) $5 \mathrm{~h}$. Inset shows the particle size distribution. 

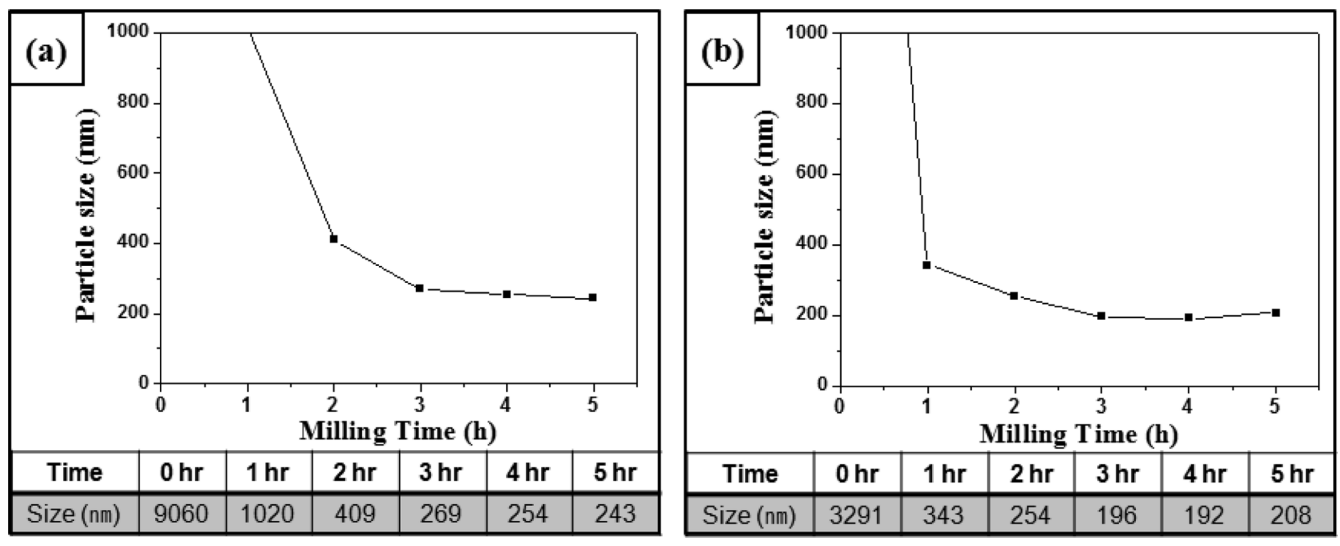

Fig. 8. Mean particle size analysis of $\mathrm{CoAl}_{2} \mathrm{O}_{4}$ blue pigment prepareds by (a) the polymerized complex method, (b) the solid state reaction with the different attrition milling time.

일반적으로 레이저회절방식 입도분석의 경우 입자가 응 집되어있을 경우 실제 입자 크기보다 입도가 크게 측정 되기 때문에, 어트리션밀링 시간에 따른 안료 입자의 크
기의 PSA 측정 결과가 Fig. 6과 Fig. 7의 FE-SEM 이 미지와 잘 일치하는 것은 어트리션밀링 후 입자가 미세 화되었을 뿐만 아니라 입자 간의 분산 또한 잘 이루어져
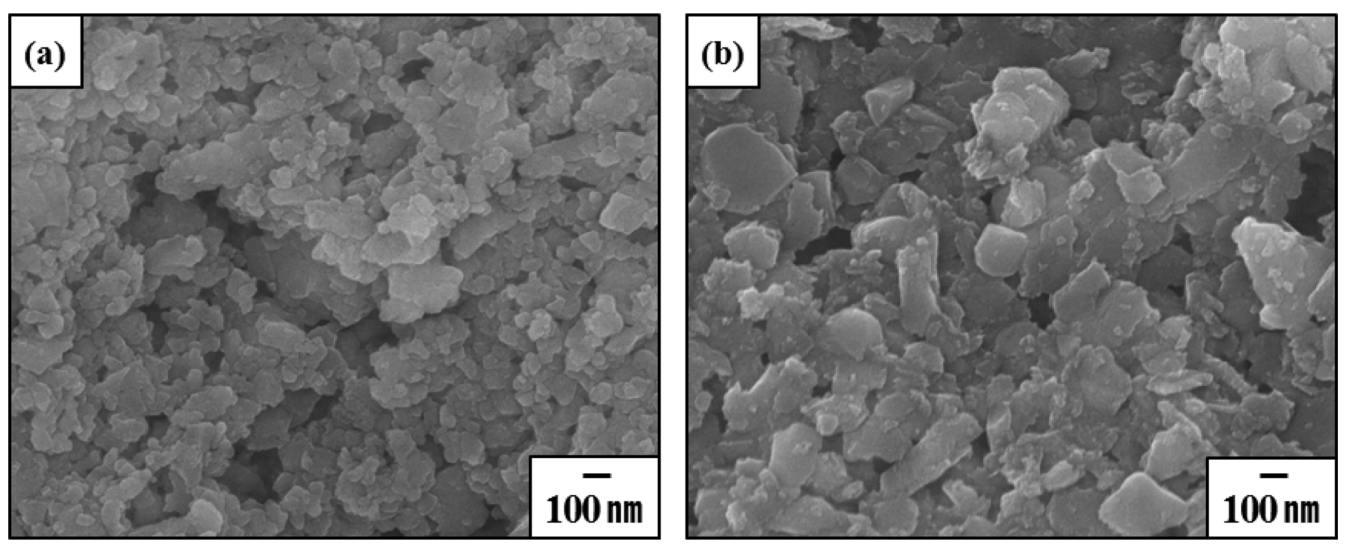

Fig. 9. SEM images of $\mathrm{CoAl}_{2} \mathrm{O}_{4}$ blue pigments prepared by (a) the polymerized complex method and (b) the solid state reaction after attrition milling for $3 \mathrm{~h}$.
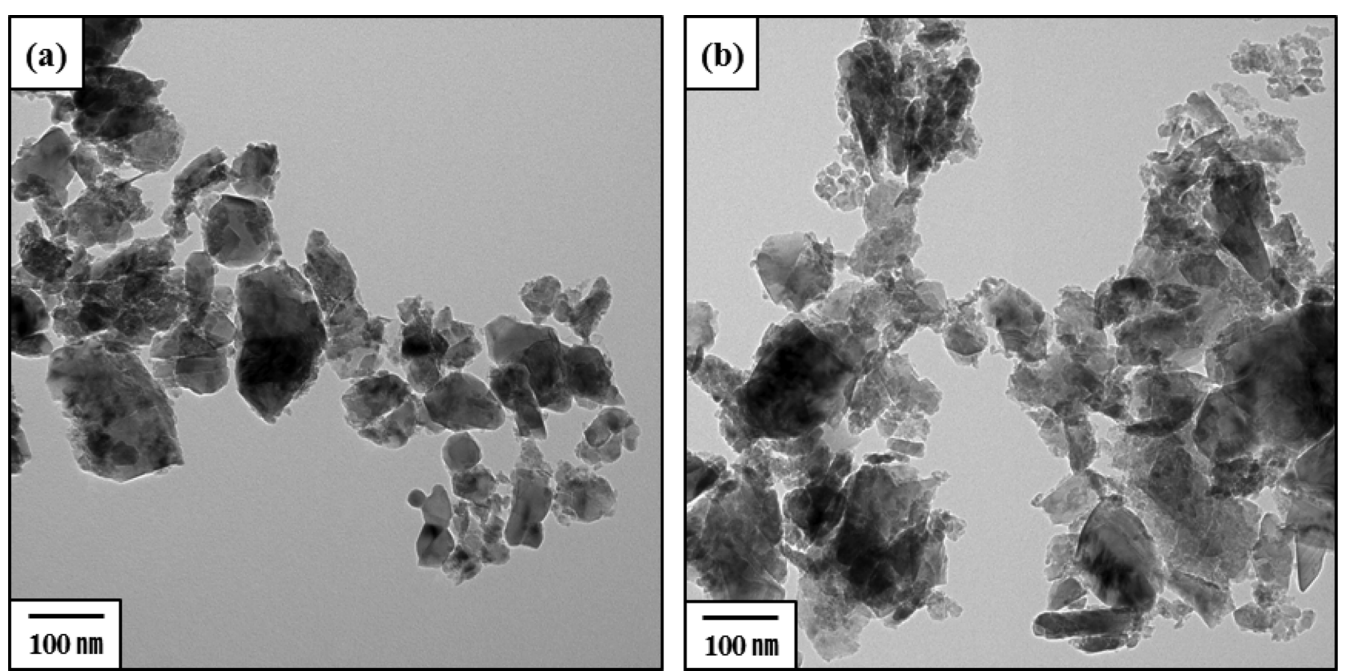

Fig. 10. TEM images of $\mathrm{CoAl}_{2} \mathrm{O}_{4}$ blue pigments prepared by (a) the polymerized complex method and (b) the solid state reaction after attrition milling for $3 \mathrm{~h}$. 
있는 것으로 보여진다.

Fig. 9와 Fig. 10은 3시간 동안 어트리션밀링을 진행 한 두 가지 안료 입자의 고배율 FE-SEM 및 HR-TEM 이미지이다. 착체중합법과 고상합성법을 통하여 합성된 안료 입자 모두 어트리션밀링을 통하여 약 100 200 nm 의 크기로 분쇄된 것을 보여주고 있다. 또한 Fig. 4(a)와 Fig. 5(a)의 초기 시편과 달리 응집된 2차 입자가 존재하 지 않는 것을 TEM 이미지에서 관찰 할 수 있었기 때문 에 어트리션밀링에 의해 응집되어 있던 안료입자의 분산 및 입도 감소가 이루어 졌으며, 잉크젯 프린팅에 응용이 가능한 $200 \mathrm{~nm}$ 이하의 나노 안료를 얻을 수 있었다.

3.3. $\mathrm{CoAl}_{2} \mathrm{O}_{4}$ 청색 나노 무기 안료의 결정구조 및 색 분석

어트리션밀링 공정 후 안료 입자의 미세화에 의한 결 정구조 및 안료 색상 변화를 확인하기 위해 $\mathrm{XRD}$ 와 $\mathrm{CIE} \mathrm{L*a*b*} \mathrm{측정을} \mathrm{실시하였다.} \mathrm{Fig.} 11$ 는 두 가지 합 성법으로 합성한 $\mathrm{CoAl}_{2} \mathrm{O}_{4}$ 청색 무기 안료의 어트리션밀
링 전 후 XRD 분석 결과를 보여주고 있다. 어트리션밀 링 전 착체중합법과 고상합성법으로 합성된 안료는 스피 넬 구조를 가지는 $\mathrm{CoAl}_{2} \mathrm{O}_{4}$ 단일상을 가지고 있으며 어 트리션밀링 후에도 $\mathrm{CoAl}_{2} \mathrm{O}_{4}$ 단일상을 유지하지만, 안료 입자의 미세화로 인해 XRD 피크의 반가폭(FWHM, full width at half maximum)이 증가하고 피크의 강도가 다소 감소한 것을 보여주고 있다.

어트리션밀링 전 후 안료의 색상 변화를 확인하기 위 해 CIE L*a*b* 측정을 진행하였다. Fig. 12 는 두 가지 합성법으로 합성한 $\mathrm{CoAl}_{2} \mathrm{O}_{4}$ 청색 무기 안료의 어트리션 밀링 전후 $\mathrm{CIE} \mathrm{L*a*b*의} \mathrm{변화를} \mathrm{보여주고} \mathrm{있다.} \mathrm{착체중}$ 합법으로 합성한 $\mathrm{CoAl}_{2} \mathrm{O}_{4}$ 청색 무기 안료는 어트리션밀 링 전 $\mathrm{L}$ 값이 30.53 , $\mathrm{a}$ 값이 $-6.41, \mathrm{~b}$ 값이 -27.27 을 나타 내었으며 어트리션밀링 후 $\mathrm{L}$ 값이 35.34 , a값이 -11.08 , $\mathrm{b}$ 값이 -32.37 을 나타내었다. 고상합성법으로 합성한 경 우에는 어트리션밀링 전 $\mathrm{L}$ 값이 42.98 , $\mathrm{a}$ 값이 $-13.45, \mathrm{~b}$ 값이 -37.82 에서 어트리션밀링 후 $\mathrm{L}$ 값이 38.97 , $\mathrm{a}$ 값이 $-8.69, \mathrm{~b}$ 값이 -32.37 로 변하였다. 두 가지 안료 모두 어 트리션밀링 후 $\mathrm{L} * \mathrm{a} * \mathrm{~b} *$ 값의 변화는 약간 있었지만 여전
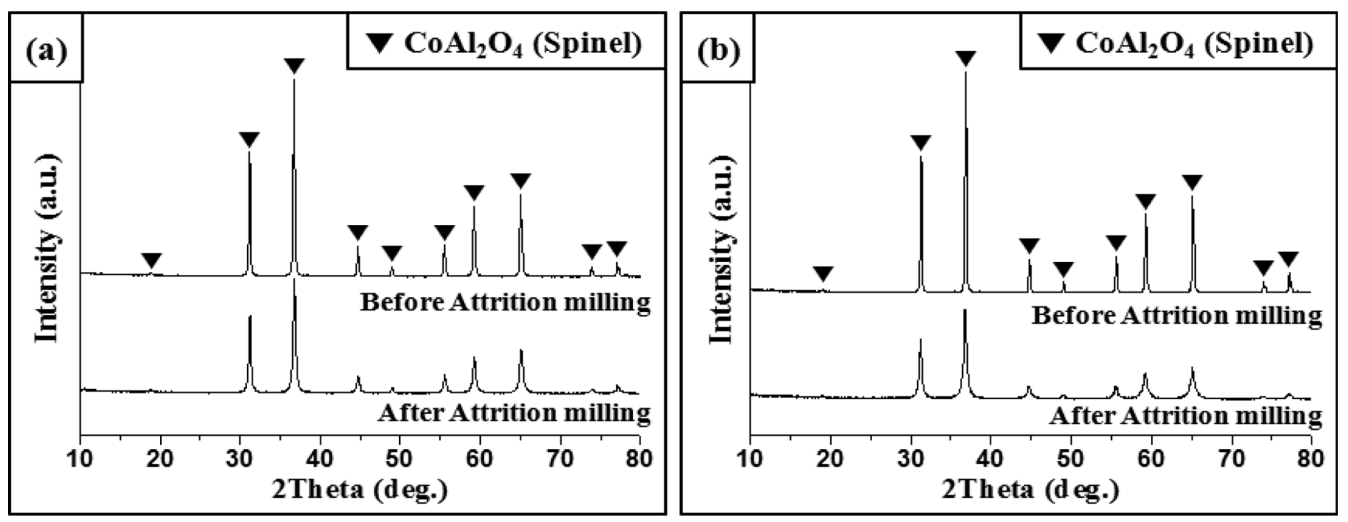

Fig. 11. XRD spectra of $\mathrm{CoAl}_{2} \mathrm{O}_{4}$ blue pigments prepared by (a) the polymerized complex method and (b) the solid state reaction before and after the attrition milliing for $3 \mathrm{~h}$.
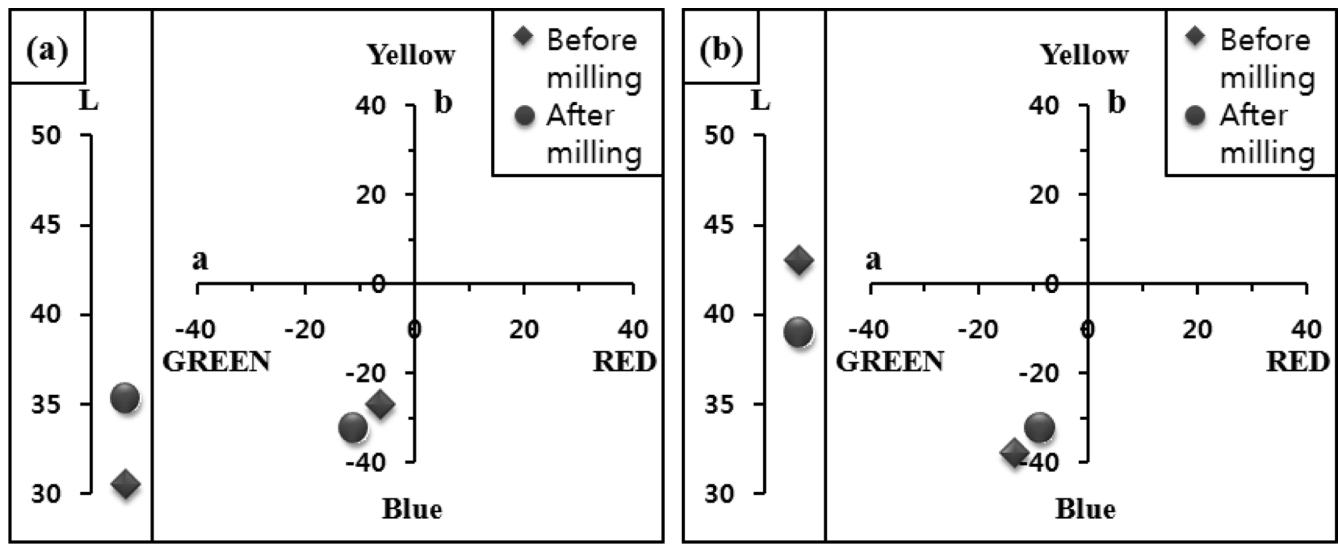

Fig. 12. CIE L*a*b* results of $\mathrm{CoAl}_{2} \mathrm{O}_{4}$ blue pigments prepared by (a) the polymerized complex method and (b) the solid state reaction before and after the attrition milling for $3 \mathrm{~h}$. 

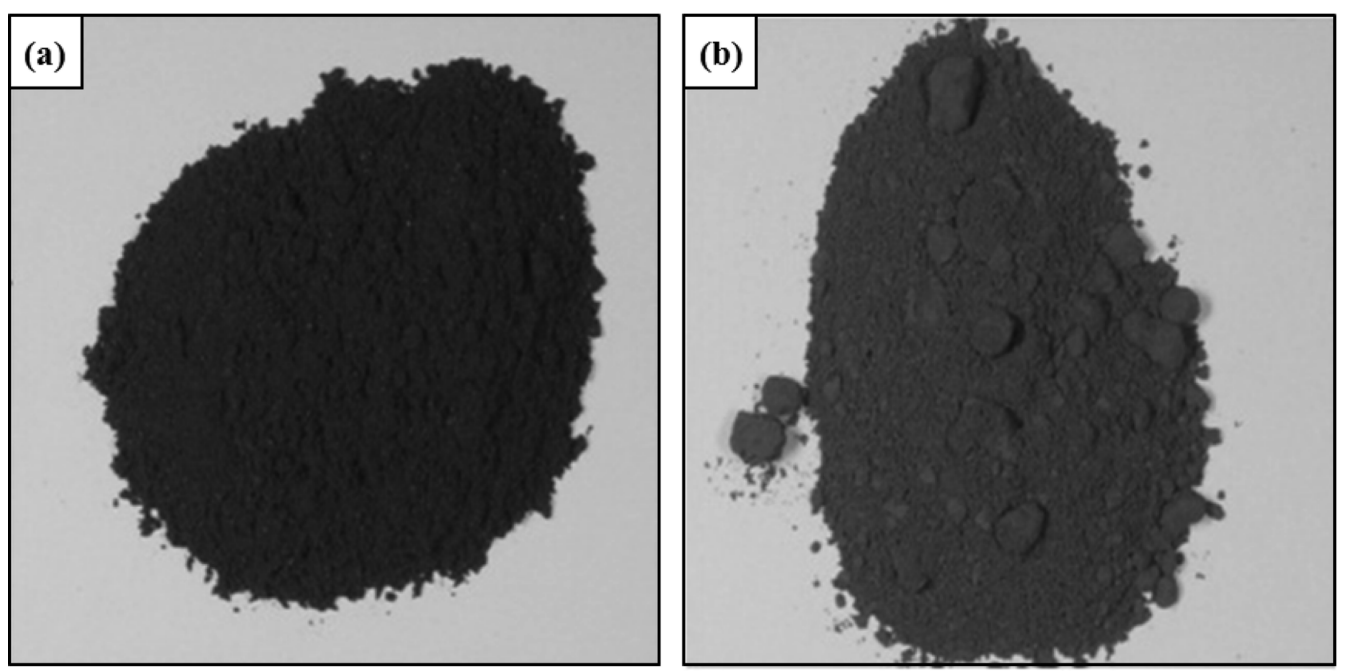

Fig. 13. Optical images of $\mathrm{CoAl}_{2} \mathrm{O}_{4}$ blue pigments prepared by the polymerized complex method (a) before and (b) after the attrition milling for $3 \mathrm{~h}$.
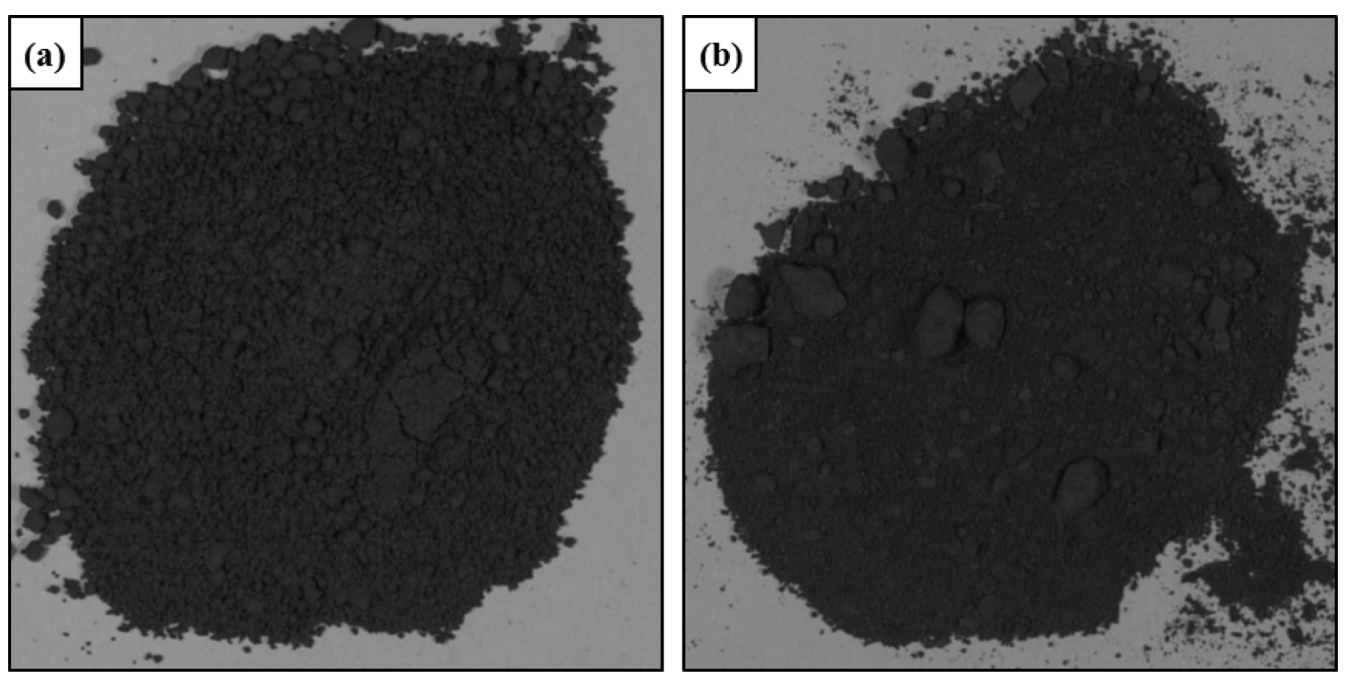

Fig. 14. Optical images of $\mathrm{CoAl}_{2} \mathrm{O}_{4}$ blue pigments prepared by the solid state reaction (a) before and (b) after the attrition milling for $3 \mathrm{~h}$.

히 안정적으로 청색을 발색하는 것을 확인하였다.

FIg. 13과 Fig. 14는 두 가지 합성법으로 합성한 $\mathrm{CoAl}_{2} \mathrm{O}_{4}$ 청색 무기 안료의 어트리션밀링 전 후 색상 변 화를 보여주는 사진이다. 착체중합법의 경우 밀링 후 색 상이 다소 밝아졌는데, 이는 Fig. 12 의 CIE L*a*b* 측 정에서 볼 수 있듯이 L값이 30.53에서 35.34로 명도 값 이 증가하였기 때문이다. 반대로 고상합성법의 경우 $\mathrm{L}$ 값 이 42.98에서 38.97로 감소하여 명도 값이 감소하였기 때문에 안료의 색상이 약간 어두워진 것을 관찰하였다. 어트리션밀링 전의 $\mathrm{CoAl}_{2} \mathrm{O}_{4}$ 청색 안료 분말은 합성 방 법에 따라 1 차 입자 크기, 응집도, 하소 온도 등의 차이 로 인해 $\mathrm{CIE} \mathrm{L*a*b*} \mathrm{측정} \mathrm{결과에서} \mathrm{다소의} \mathrm{색상} \mathrm{차이}$ 가 관찰되었으나 어트리션밀링을 진행한 후에는 사용된 지르코니아 볼과 회전팔에서 마모되어 나온 소량의
$\mathrm{ZrO}_{2}$ 미세입자의 영향과 두 시편의 안료 입자 크기가 모두 약 $200 \mathrm{~nm}$ 크기로 일정해 짐에 따른 광학적 산란 효과가 비슷해져 이 결과 최종적으로 두 가지 안료가 비 슷한 색상을 나타내게 된 것으로 사료된다.

\section{4. 결 론}

$\mathrm{CoAl}_{2} \mathrm{O}_{4}$ 청색 무기 안료를 착체중합법과 고상합성법 을 통하여 합성하였고, 잉크젯 프린팅 공정의 응용을 목 적으로 고에너지 밀링 공정 중 하나인 어트리션밀링을 통해 미세화하고자 하였다. 착체중합법과 고상법으로 합 성된 $\mathrm{CoAl}_{2} \mathrm{O}_{4}$ 청색 무기 안료들은 $\mathrm{XRD}$ 를 통하여 스피 넬 결정구조의 $\mathrm{CoAl}_{2} \mathrm{O}_{4}$ 단일상을 가지는 것을 확인하였 
으며 응집으로 인해 2 차 입자가 수 $\mu \mathrm{m}$ 크기를 나타내 었다. 이들 합성 안료들을 어트리션밀로 밀링한 후 FESEM, HR-TEM 이미지를 통해 밀링 시간에 따른 안료 입자의 크기 변화를 확인하였으며, 3시간의 밀링 공정 후 두 시료 모두 $200 \mathrm{~nm}$ 의 크기로 안료 입자의 미세화 가 이루어졌다. 또한 안료 입자 응집의 완화로 분산이 이루어져 FE-SEM, HR-TEM 이미지와 일치하는 입도 분석결과를 얻을 수 있었다. 어트리션밀링 후 $\mathrm{CoAl}_{2} \mathrm{O}_{4}$ 나노 무기 안료의 결정성을 분석한 결과 입자 크기 감소 로 인해 XRD 피크의 강도가 다소 감소하였으나 $\mathrm{CoAl}_{2} \mathrm{O}_{4}$ 단일상이 안정적으로 유지되고 있는 것을 확인하였다. $\mathrm{CIE} \mathrm{L}^{*} \mathrm{a} \mathrm{b}^{*}$ 측정을 통한 색상 분석 결과 어트리션밀링 후 착체중합법으로 합성된 무기 안료 입자의 경우 $\mathrm{L}$ 값 이 $35.34, \mathrm{a}$ 값이 $-11.08, \mathrm{~b}$ 값이 -32.37 을 가졌고, 고상 합성법으로 합성된 무기 안료 입자의 경우 L값이 38.97 , $\mathrm{a}$ 값이 $-8.69, \mathrm{~b}$ 값이 -32.37 을 나타내었으며 모두 청색을 발색하는 것을 확인하였다. 어트리션밀링을 통해 $200 \mathrm{~nm}$ 이하의 입자 크기를 가지는 청색 나노 무기 안료를 얻을 수 있었고, 잉크젯 프린팅용 청색 세라믹 잉크 제조에 응용이 가능할 것으로 보여진다.

\section{감사의 글}

본 논문은 미래창조과학부 - 산업통상자원부가 공동지 원한 '나노융합2020사업'으로 지원된 연구결과입니다[잉 크젯프린팅 포셀린제품용 고화도 나노세라믹 발색잉크 제조].

\section{참 고 문 헌}

[ 1 ] P.H. Bolt and M.P.H.F. Habraken, "Formation of nickel, cobalt, copper, and iron aluminates from $\alpha$ - and $\gamma$-alumina-supported oxides: A comparative study", J. Solid State Chem. 135 (1998) 59.

[2 ] J.M.F. Colinas and C.O. Arean, "Kinetics of solid-state spinel formation: Effect of cation coordination preference", J. Solid State Chem. 109 (1994) 43.

[ 3 ] W.S. Cho and M. Kakihana, "Crystallization of ceramic pigment $\mathrm{CoAl}_{2} \mathrm{O}_{4}$ nanocrystals from $\mathrm{Co}-\mathrm{Al}$ metal organic precursor", J. Alloys Compd. 287 (1999) 87.

[4] N. Ouahdi, S. Guillemet, B. Durand, R. El Ouatib, L. Er Rakho, R. Moussa and A. Samdi, "Synthesis of $\mathrm{CoAl}_{2} \mathrm{O}_{4}$ by double decomposition reaction between $\mathrm{LiAlO}_{2}$ and molten $\mathrm{KCoCl}_{3}$ ”, J. Eur. Ceram. 28 (2008) 1987.

[ 5 ] W. Lv, Q. Qiu, F. Wang, S. Wei, B. Liu and Z. Luo, "Sonochemical synthesis of cobalt aluminate nanoparticles under various preparation parameters", Ultrason. Sonochem. 17 (2010) 793.

[6] J. Azurdia, J. Marchal and R. M. Laine "Synthesis and characterization of mixed-metal oxide nanopowders along the $\mathrm{CoO}_{\mathrm{x}}-\mathrm{Al}_{2} \mathrm{O}_{3}$ tie line using liquid-feed flame spray pyrolysis", J. Am. Ceram. Soc. 89 (2006) 2749.

[ 7 ] D. Gardini, M. Dondi, A. L. Costa, F. Matteucci, M. Blosi and C. Galassi, "Nano-sized ceramic inks for drop-on-demand ink-jet printing in quadrichromy", J. Nanosci. Nanotechnol. 8 (2008) 1979.

[ 8 ] I. Fasaki, K. Siamos, M. Arin, P. Lommens, I. VanDriessche, S.C. Hopkins, B.A. Glowacki and I. Arabazis, "Ultrasound assisted preparation of stable waterbased nanocrystalline $\mathrm{TiO}_{2}$ suspensions for photocatalytic applications of inkjet-printed films", Appl. Catal. A 411-412 (2012) 60.

[9] Z. Hu, M. Xue, Q. Zhang, Q. Sheng and Y. Liu, "Nanocolorants: A novel class of colorants, the preparation and performance characterization", Dyes Pigm. 76 (2008) 173.

[10] P.M.T. Cavalcante, M. Dondi, G. Guaini, M. Raimondo and G. Baldi, "Colour performance of ceramic nano-pigments", Dyes Pigm. 80 (2009) 226.

[11] I. Nettleship, J.L. Shull and W.M. kriven, "Chemical preparation and phase stability of $\mathrm{Ca}_{2} \mathrm{SiO}_{4}$ and $\mathrm{Sr}_{2} \mathrm{SiO}_{4}$ ", J. Eur. Ceram. 11 (1993) 291.

[12] B.R. Son, D.H. Yoon, K.S. Han, W.S. Cho, K.T. Hwang and J.H. Kim, "Synthesis of $(\mathrm{Ni}, \mathrm{Mg}) \mathrm{Al}_{2} \mathrm{O}_{4}$ ceramic nano pigment by a polymerized complex method", J. Kor. Ceram. Soc. 50 (2013) 195.

[13] D.W. Lee, J.H. Won and K.B. Shim, "Low temperature synthesis of $\mathrm{BaCeO}_{3}$ nano powders by the citrate process", Materials Letters 57 (2003) 3346.

[14] R. Muñoz, N. Masó, B. Julián, F. Márquez, H. Beltrán, P. Escribano and E.Cordoncillo, "Environmental study of $\mathrm{Cr}_{2} \mathrm{O}_{3}-\mathrm{Al}_{2} \mathrm{O}_{3}$ green ceramic pigment synthesis", J. Eur. Ceram. 24 (2004) 2087.

[15] W. Hajjaji, C. Zanelli, M.P. Seabra, M. Dondi and J.A. Labrincha, "Cr-doped perovskite and rutile pigments derived from industrial by-products", Chem. Eng. J. 171 (2011) 1178. 